$\begin{array}{ll}\text { NAMA } & : \text { MIRNA RAFKI } \\ \text { NIM } & : 90100118012 \\ \text { KELAS } & : \text { EKONOMI ISLAM (A) } 2018\end{array}$

\title{
KONSEP EKONOMI PADA MASA NABI MUHAMMAD SAW
}

Berbicara tentang ekonomi islam tentu berhubungan dengan kehidupan manusia yang berlandaskan pada prinsip-prinsip syariat islam. Islam itu sendiri datang bertepatan dengan diangkatnya Muhammad selaku Rasulullah. Dikala itu pada masa periode Makkah perekonomian masih sangat sederhana, dikarenakan beliau belum sempat membangun perekonomian. Barulah saat beliau hijrah ke Madinah beliau mulai membangun perekonomian, kondisi Madinah dikala itu masih sangat kacau karena Madinah saat itu belum mempunyai pemimpin. Datangnya Rasulullah ke Madinah di sambut baik oleh masyarakat serta dengan berjalannya waktu diangkatlah Rasulullah jadi Pemimpin yang terdiri dari pengikut ajaran agama islam yang jumlahnya setiap hari terus meningkat. Dibawah kepemimpinan Rasulullah, Madinah tumbuh pesat dalam waktu 10 tahun. Rasulullah membangun perekonomian di Madinah sesudah urusan politiknya berakhir. Dimana Rasulullah menempatkan Al-Qur'an jadi dasar-dasar ekonomi. Norma serta etika ditempatkan pada posisi yang berarti serta menjunjung tinggi keadilan yang etis yang relevan dengan ajaran islam. Tidak hanya itu, pada masa Rasulullah telah diterapkan larangan bunga ataupun riba sebagaimana yang biasa kaum yahudi lakukan.(Mudiiah, 2016).

Pada masa itu, masyarakat Madinah menempatkan pasar selaku mekanisme ekonomi yang sangat berarti, karena harga pasar yang dibentuk dengan sistem keadilan sangat dihargai oleh Rasulullah. Rasulullah sangat mewajibkan adanya kredibilitas, transparansi, dan penyeimbangan terhadap intervensi harga.(Parakkasi, H. Idris, 2018). Dimana, sebagian besar penduduk Madinah mata pencahariannya ialah berdagang, dan sebagain lagi bertani, berkebun dan beternak. Tidak hanya itu, disebababkan keadaan perekonomian yang sulit dimasa Rasulullah hijrah kemadinah sehingga dikala itu belum diwarisi sumber keuangan, 
sehingga Rasulullah meletakkan dasar kehidupan bermasyarakat seperti membangun masjid dan Menjalin persaudaraan antara kaum Anshar dengan kaum Muhajirin.

Rasulullah merupakan pemimpin pertama pada abad ke tujuh yang mempraktikkan konsep baru di bidang keuangan Negara. Dimana seluruh hasil kekayaan Negara dikumpulkan setelah itu di keluarkan sesuai dengan kebutuhan Negara. Lembaga pengumpulan dana dikala itu di sebut Baitul Maal. Pendapatan Negara disimpan setelah itu disalurkan kepada masyarakat. Sumber pendapatannya tidak hanya bersumber dari zakat saja namun juga bersumber dari kharaj, khums, jizyah, serta penerimaan lain, seperti kaffarah serta harta waris dari orang yang tidak menjadi ahli waris. Dari pemasukan Baitul Maal tersebut setelah itu dikeluarkan untuk lebih menyebar luaskan ajaran agama islam, untuk pendidikan, kebudayaan, membangun infrastruktur serta pelayanan kesejahteraan sosial.(Fauzan, 2019).

\section{DAFTAR PUSTAKA}

Fauzan, I. (2019). Pemikiran Ekonomi Islam Pada Masa Nabi Muhammad. Risalah, Vol.5, No.(1).

Mudiiah, K. (2016). Analisis Sejarah Pemikiran Ekonomi Masa Klasik. Iqtishada, 8(2), 189-210.

Parakkasi, H. Idris, dan K. (2018). Analisis Harga dan Mekanisme Pasar dalam perspektif islam. Laa Maysir, 5(1). 